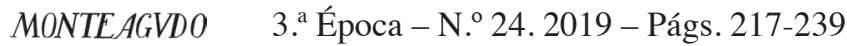

\title{
UN PALIMPSESTO INDESEADO EN LA OBRA LITERARIA de Juan Benet: Julio Cortázar y sus MINÚSCULAS PEDANTERÍAS
}

\author{
Jorge Machín LuCAS \\ The University of Winnipeg
}

\section{RESUMEN:}

Se estudia la influencia de Julio Cortázar en Juan Benet, partiendo de las entrevistas hechas a este último. Este lo criticó con virulencia y superficialmente pero, tras un estudio comparativo de sus respectivas obras literarias, se han advertido una serie de concomitancias entre ellos. Ambos relativizaron y descentraron los conceptos de realidad, de lógica y de tiempo y sus instrumentales epistemológicos, narratológicos o lingüísticos. Lo hicieron para elevar el nivel intelectual de los lectores y para así poder penetrar más en lo irracional, espacio de una razón «ultraperceptible» útil para nuestra evolución.

\section{PALABRAS CLAVE:}

Cortázar, Benet, palimpsesto, intertextualidad, postmodernidad.

\begin{abstract}
:
I study Julio Cortázar's influence in Juan Benet, based on the interviews made to the latter. $\mathrm{He}$ criticized him with virulence and superficially but, after a comparative study of their respective literary works, I found some similarities between both of them. They minimized and decentered the concepts of reality, logic and time as much as they did it with their epistemological, narratological or linguistic tools. They did that in order to raise the intellectual level of the readers and so as to penetrate more in the irrational, the space of a reason beyond perception and useful for our evolution.
\end{abstract}

\section{KEYWORDS:}

Cortázar, Benet, palimpsest, intertextuality, postmodernity.

En la segunda mitad del siglo XX, el mundo intelectual hispano se vio revolucionado por un cambio en las formas y en los contenidos literarios. De él fueron responsables, entre otros autores, el escritor argentino Julio Cortázar (1914-1984) y el español Juan Benet (1927-1993). Sus obras son de la máxima calidad intelectual y estilística. A pesar de ser diferentes, ofrecen una serie de parecidos que con alta probabilidad muestran una relación intertextual entre sus textos, lo que Bloom llamaría la ansiedad de la influencia o un mapa de malas lecturas siguiendo la expresión 
utilizada por él en sus ensayos The Anxiety of Influence y A Map of Misreading. Son lecturas deficientes ya que el que las asimila las transforma deliberada o inconscientemente por desprecio a un mentor que le ha educado en exceso o que lo ha hecho en una dirección inicialmente no deseada. De esta manera, estos se neutralizan para producir una nueva escritura polifónica o poligráfica (Kristeva 1981: 206,248) y, por consiguiente, una serie infinita de nuevas lecturas que dependen de la interpretación guiada, pero a la vez libre, del lector.

Benet reconoció haber leído a Cortázar. Presionado por ciertos fanáticos suyos, confesó haber leído Bestiario (1951), Historias de cronopios y de famas (1962), Rayuela (1963) y Todos los fuegos el fuego (1966) y conocer también La vuelta al día en ochenta mundos (1967). Dijo que no le gustaba, que le aburría, que le parecía «estomagante». Calificó a su autor, con su típico y no siempre justo verbo acerado, impulsivo y a veces simplista, como un pedante, como un mediocre que no sabía escribir y como un excelente escritor de sucesos minúsculos que no valía para escribir obras largas (Cartografía, 1997: 46-7, 50, 52, 66-7, 156-7). Ambos rechazaron los métodos del realismo tanto como ese pacto estamental de la razón en que vivimos y toda estructura e ideología literaria suyas. En consecuencia, en el presente artículo se van a estudiar una serie de puntos que demuestran esta influencia de Cortázar en Benet tanto por reacción como por acción, siguiendo la ficción que más comenta de ellas, su obra maestra Rayuela. Ello nos va a servir para delimitar las líneas medulares de las letras y de la actividad cultural en general de toda una época. También se verán los puntos en común entre tantos otros autores que cuestionaron la literatura y la cultura de sus tiempos. En esa época, imperaban el estudio y el análisis de lo que muy superficialmente denominamos como realidad, esa que es inmediatamente perceptible por los sentidos y que no es más que una entelequia consensuada socialmente por infinitud de subjetividades. Es la que se basa en el examen sociopolítico y económico de los hechos que conocemos y la que ignora todo aquello que pueda existir más allá de la percepción y de la conceptualización actuales de nuestras mentes en estado de evolución.

La obra de Cortázar que más influyó, consciente o inconscientemente, en Benet fue Rayuela, toda una «contranovela» o «antinovela» publicada cuatro años antes que Volverás a Región (1967), la primera novela del español. Machín Lucas estudió este diálogo como uno tal vez consciente o subconsciente aunque en este artículo se va a discutir como todo un palimpsesto de pleno derecho con nuevas y más afinadas interpretaciones («Diálogos [...], 2018») a la luz de nuevos y definitivos hallazgos extraídos de sus entrevistas recogidas en el libro titulado Cartografía personal. Ambas obras y ambas trayectorias literarias coinciden en el hecho de que tratan de penetrar en los procelosos terrenos de lo que mal denominamos como irreal, irracio- 
Un palimpsesto indeseado en la obra literaria de Juan Benet: Julio Cortázar...

nal o antirracional, aquellas partes de lo real que no percibimos pero que sin duda existen ya que nuestros sentidos están limitados. Para ello, experimentan con nuevas estrategias ideológicas y narratológicas que se discutirán en breve. En el caso de la obra de Cortázar, esta es una especie de rompecabezas, como bien advirtió Jakfalvi (2004: 16), que rompe con la lógica y con el discurso tradicionales. Benet hace algo similar al dispersar la breve trama argumental, llena de deliberadas inexactitudes y contradicciones. En las obras de ambos, la forma y el estilo importan más que el argumento, aunque no más que el nuevo contenido que se genera con estos cambios, uno lleno de indeterminaciones e incertidumbres semióticas y semánticas. De este creen que puede surgir una nueva vía de conocimiento para entender «lo real» más allá de nuestra percepción común. En definitiva, no se puede localizar una línea argumental principal, sino muchas que se cruzan y que se mezclan, todas ellas dispuestas en un «ordenado» desorden cronológico. Con esta estrategia narrativa, se imitan los vaivenes de la relativa percepción de la realidad. Se trata así de representar cómo la conciencia examina, analiza y recuerda a la anterior.

Con esta intención, ambos utilizan un estilo complejo y sutil en cuanto a lo conceptual, el cual es poco atractivo para todos aquellos lectores que quieran tan solo relajarse o evadirse a través de la lectura de estas obras. No se busca descubrir ni sustentar verdades categóricas. No se afirma tajantemente nada. Se especula y se divaga muchas veces con excursos o digresiones. En él proliferan la abundancia verbal y las frases largas y retorcidas, llenas de subordinadas, sobre todo en el caso de Benet. Se fuerza la gramática hasta cometer a veces errores de sintaxis o solecismos, lo que es una manera de demostrar que esa realidad ulterior se puede encontrar más allá de las constricciones de un sistema negociado por imperfectos seres humanos. Se utilizan también extranjerismos o xenismos para intentar expandir los significados y, por ende, la realidad. No obstante, ninguno de estos excesos es innecesario epistemológicamente para el lector más habituado a este tipo de retóricas del desconcierto. Son maneras de generar nuevas matrices de conocimiento, algo de lo que nos habla Minardi al respecto de la obra benetiana (2012: 198), aunque bien es cierto que esto es aplicable a cualquier otra.

El crítico y escritor Aguilar Monsalve, gran conocedor de la figura literaria de Cortázar, afirma que este rompe con el realismo desde el culturalismo, lo absurdo, lo ilógico, el surrealismo y lo onírico («Lo fantástico [...]», 2012: 56). Este estilo que parece querer imitar la realidad de nuestra corriente de conciencia y de nuestra habla está repleto de técnicas novedosas. Una de ellas es el uso de dos textos simultáneos en las líneas pares e impares con tal de generar un tercero inesperado, producido por la caprichosa mente del lector y por las expectativas que le ofrecen sus circunstancias y su formación. Otras son los deliberados errores ortográficos, las frases sin 
acabar, la técnica del «simultaneísmo», los neologismos, los juegos de palabras o las aliteraciones o repeticiones de sonidos. Benet, por su parte, intenta hacer lo mismo mediante la creación y articulación de un nuevo tipo de Grand Style que, a su no muy modesto parecer, entró en decadencia con la muerte de Cervantes, tal y como lo expresa en su primer y más emblemático libro de ensayos titulado La inspiración y el estilo (1973). Con este propósito, él usa y abusa de un paródico lenguaje entre lo narrativo, lo lírico, lo científico, lo editorial, lo filosófico y lo psicológico del monólogo interior. No muy lejos está esta estrategia narrativa del arte de Cortázar, amante de la mezcla multigenérica y multiestilística.

Por poner un ejemplo de un aspecto inusual en novela, está su imitación del proceso editorial de un texto. De esta forma, buscan, desde la confluencia entre narración y tratado ensayístico y entre narrador, filólogo y editor, abrir un nuevo espacio de conocimiento al intensificar su distanciamiento del contenido y del estilo realistas. Las notas de a pie que por momentos usan Cortázar y Benet (este último, sobre todo, en Volverás a Región y en Un viaje de invierno (1972)) buscan construir una suerte de narrador-editor entre lo experiencial, lo académico y lo erudito. Este servirá para que el lector asuma la plena autorreferencialidad de la diégesis y lo ahistórico de la trama de una «novela ombligo» o navel novel, entre la parodia y la ironía intelectual. Además, de este modo se le hace entender que «lo real» ha surgido como concepto vital y cultural de una multiplicidad de fuentes, algo de lo que somos conscientes en muy pequeña parte. Todo esto también enfatiza el carácter fenoménico del texto y le da autonomía epistemológica. Ese es uno en el cual se plasman numerosos códigos y fuentes de la tradición y del presente. Es una fuente de infinitas interpretaciones para un lector activo y más extensas y profundas aún cuanto más cultivado esté.

En cuanto a este lector, ambos elevan el nivel intelectual, estilístico y narratológico en sus novelas para forzarle a una respuesta más abierta y más inteligente y para mejorar su nivel de comprensión, aparte de para demostrar su propia superioridad intelectual como escritores que no se dejan engañar por las trampas del sistema en que vivimos. Esto ha sido muy discutido. Se les ha acusado de pedantería, ya que más que desarrollar el nivel medio de los lectores han conseguido convertir estas lecturas en placer de minorías educadas y en suplicio de mayorías que buscan en la lectura tan solo un momento de ocio. Muchos lectores sin formación académica ni se han acabado de leer sus novelas o, bastantes veces, a duras penas las han comenzado. Este deseo encubierto de elitismo intelectual ha convertido a sus connotadas novelas en unas de amplios significados que se desplazan constantemente de los centros del saber pactado hacia unos márgenes inexplorados o escasamente transitados. Ellas están en permanente metamorfosis ya que no 
Un palimpsesto indeseado en la obra literaria de Juan Benet: Julio Cortázar...

se leen de manera convencional y porque cada lector con sus diferentes expectativas las transforma en algo único, mucho más que lo que puede suceder en las más denotadas novelas realistas con su dicción directa, con su apego a la cronología y con sus intencionales omnisciencia, guía y estrechez semiótica.

Véase este ejemplo. En el capítulo 79 de Rayuela, en el que Cortázar expone sus ideas estéticas y (meta)literarias acerca de la «antinovela» que está creando a través de Morelli, uno de sus alter egos, se unen ficción y realidad. Allí expresa su proyecto de buscar un lector «cómplice», que participe simultáneamente en la creación semiótica de la obra (Ibid. 453) y que explore el misterio (Ibid. 454). Esto se opone a la poética del novelista clásico que desea enseñar a través de su obra y a la del romántico que «[...] quiere ser comprendido por sí mismo o a través de sus héroes» (Ibid. 453). Estos dos han buscado transformar al lector, educarlo en lo vital y/o en lo artístico y que les comprenda, que sienta que puede compartir sus experiencias. Por el contrario, Cortázar aspira «[...] a mutarlo, a desplazarlo, a extrañarlo, a enajenarlo» (Ibid. 497-8). Benet busca también estimular e incluso crear un lector activo sin cerrar semióticamente el mensaje narrativo con argumentos mínimos, dispersos, abiertos y a veces incoherentes o contradictorios, producto de la premeditación o de una deliberada despreocupación de un escritor más interesado en las ideas y en el estilo. Esto contrarresta la obsesión arquitectónica de tantos escritores por edificar una novela perfecta y sin fisuras. Por ejemplo, este ha sido el caso de los novelistas del realismo. Su intento de fijar y de representar la realidad social les ha quitado tiempo y entorpecido su capacidad de reflexión para el desarrollo de ideas originales y brillantes. En contraposición a esto, Benet esquiva todo orden cronológico en la diégesis e impone el de la conciencia de los personajes, influido por la filosofía de Henri Bergson, del que se hablará más adelante en cuanto al tratamiento del tiempo. También hace prevalecer el tiempo autoconsciente y metaliterario del escritor y los de sus múltiples narradores que arteramente manipulan la materia tratada. Así trata de imitar el libre fluido de la conciencia con un estilo que está diseñado hábilmente y que nunca es tan espontáneo como se pretende aparentar.

Hay más similitudes que hacen sospechar que el uso benetiano de ciertas técnicas está influido por el magisterio de Cortázar, aun a pesar de las reconvenciones del primero a la poética de la prosa del segundo. Sus novelas postmodernas, con tonos obviamente metaliterarios que son paródicos de los géneros imitados, tienden a la «autorreflexión». Por momentos, parecen ensayos novelados o disertaciones narradas, algo despreciado por los defensores de la narratividad a toda costa. De este modo, los dos quieren dar un salto en la tradición mientras la critican duramente, aunque la usan también como modelo, a veces para intentar mejorarla y a veces para tratar de revertirla o de deconstruirla. Creen que ella ha aceptado y expandido, 
con fines antientrópicos, ciertas ideas generales acerca de la constitución del mundo y de la sociedad más por intereses de grupo y por miedo a posibles represalias de las fuerzas del orden que por una creencia absoluta en su razón, en su justicia y en su idoneidad. Hay que conectar a este respecto estas actitudes con el compromiso izquierdista de ambos autores, mayor en lo vital que en lo eminentemente autorreferencial de sus ficciones.

Paradójicamente, estos así se oponen, con lo plural de su apuesta irracional, a toda universalización del saber en lo literario de los que desde la izquierda, con un lenguaje para mayorías y con unas tramas muchas veces insustanciales y repetitivas, defienden una literatura engagé en lo político, en lo social y en lo histórico. Se enfrentan en sus páginas contra el pensamiento único de los centros de poder y económicos, de sus gobiernos y de sus voceros tanto como de algunos de sus opositores. Creen que la actitud servil al comercio y a la difusión de ideas de los autores comprometidos ha provocado que esa literatura no haya pasado la prueba del tiempo al haber dado valor exclusivo a su presente, al no haber sabido seleccionar y depurar lo narrado y al no haber experimentado nuevas fórmulas para mejorar y elevar el estilo. La noción de progreso de Cortázar y de Benet en lo ideológico y en lo estético se opone a la historia oficial, la que se construye desde los parlamentos y los bancos, pero trata de sentar las bases de una nueva historia en la que lo oficioso y lo marginal se convierten en el centro de las reflexiones. Allí entran lo irracional, sus antihéroes, sus acciones poco ejemplares, sus discursos ilógicos y fragmentarios y todas sus curiosas especulaciones sobre la naturaleza humana y el mundo. Es el espacio de otra lógica aún desconocida tanto como el de las estéticas kitsch, que actualizan estilos pasados sin buscar las más altas formas; el de las del camp, o sea, la recreación desenfadada de lo que ya está demodé; el de las del pastiche, o imitación fragmentaria basada en diversas fuentes; y el de las del collage o unión aparentemente inconexa de materiales diversos.

Por lo tanto, ambos escritores rupturistas se muestran contrarios a los dictados filosóficos decimonónicos del positivismo y de la sociología comtianos, de tipo procientifista. Asimismo, se oponen no solo a la simpleza estilística sino también a los maniqueos métodos sociohistóricos y a los tendenciosamente políticos que subyacen en las páginas de muchas de las novelas del realismo -tanto del siglo XIX postindustrial como del XX postfranquista-, del naturalismo y del costumbrismo. A su entender, estos movimientos literarios se han ufanado de representar una realidad que en verdad es infinita, subjetiva, relativa y engañosa. Es una que por fuerza han tenido que seleccionar y depurar literariamente. Ella solo responde a un pacto social de conocimiento compartido. Este solo tiene en cuenta lo que nuestros limitados sentidos y razón perciben y lo que les interesa a unas élites que muy aviesamente 
Un palimpsesto indeseado en la obra literaria de Juan Benet: Julio Cortázar...

nos educan en su beneficio. Tanto Cortázar como Benet tuvieron ideas progresistas -sobre todo el primero- pero ellas no son preeminentes al carácter autorreferencial de sus novelas. En ellas no prepondera el análisis de lo real ni de lo histórico ni de lo exotérico. Tampoco prevalecen el abuso hermenéutico objetivador, ni el ideológico, ni el de la historicidad, ni la arrogante divinización de un autor pseudoomnisciente, ni el interés científico en la genética o en la raza, el medio y el momento a lo Taine, ni el examen de la lucha de clases, ni las influencias de la medicina (como sucedió con la experimental de Claude Bernard en el XIX), ni el marxismo, ni el socialismo, ni el darwinismo social, entre otros sistemas que se han jactado de poseer la verdad como si fueran una religión.

A todo ello y a la insuficiente razón pactada, con su ética de mínimos, oponen la primacía de la retórica, una que fluctúa entre lo sublime y lo grotesco. Con ella convocan y materializan lo esotérico, lo no común, lo oculto, lo meramente intelectual o conceptual y lo fundamentalmente cultural e intertextual. En el caso de Cortázar esto se aprecia en un humor absurdo con tonos deudores del surrealismo de Jean Cocteau tanto como con ecos de John Keats, de Edgar Allan Poe, de Charles Baudelaire y, sobre todo, de William Faulkner. Este último autor es la influencia más notable en la obra de Benet con su prosa poética, con su uso de los monólogos interiores y con sus personajes enloquecidos. Su arte irónico también ha sido influido por la épica de la historiografía militar (Clausewitz, la Guerra Civil española...) y de la grecolatina (Jenofonte, Plutarco, Tácito, Suetonio, Amiano Marcelino...), así como por la tragedia de abolengo nietzscheano, por la mística sincrética, por Euclides da Cunha, por el antropólogo Sir James George Frazer o por Thomas Mann, entre tantas otras fuentes (víd. Machín Lucas, El primer Juan Benet, 2009: 79-145, y «Juan Benet al trasluz [...]», 2001: 28). Estos palimpsestos tuvieron un carácter nutritivo para sus ya de por sí fértiles imaginaciones.

El mundo y los fenómenos literarios que conforman, como pequeños dioses-autores, son ambiguos, anfibológicos, indeterminados e inciertos, con muchas paradojas y oximorones. Estamos en los reinos de la «indetermanencia» de Hassan, combinación de las palabras indeterminación e inmanencia en una inacabable búsqueda ontológica en el interior del ser y del texto (1987: 91), de sus esencias y de su destino con sus infinitos interrogantes, sus numerosos sinsentidos y sus múltiples absurdos. En ellos hay caminos de entrada por la lógica pero no de salida de ella. Siempre se desemboca en el océano de lo ilógico, de lo falso, de lo ficticio, uno que aporta nuevas explicaciones a la naturaleza de lo humano y de lo cósmico. No se descubren nunca verdades absolutas. Son polisémicos, de infinitas interpretaciones racionales -o irracionales-, infestados de aporías o contradicciones irresolubles y de dialécticas cuyas tesis y antítesis dan lugar a las síntesis más sorprendentes. Son universos de 
letras, muchas veces logomáquicos, en los cuales los opuestos se multiplican para confluir en la escritura.

Conviene enmarcar esta discusión acerca de los paralelismos y realimentaciones entre las obras de ficción de Cortázar y de Benet en el tema de la intertextualidad.En él se analiza la intrusión en una conciencia y en sus obras de lo que Lotman llamó como la «palabra ajena» (1976: 109). Es un proceso que va del primer escritor al segundo para transformarlos a ambos a la vez. Son los respectivos influjo e influido, emisor y receptor, hipotexto -o texto influyente- e hipertexto -o texto influido- según Genette (1997: 7). Es uno de carácter dialógico como defendía Bakhtin en The Dialogic Imagination, con duplicidades de voces que de hecho eran polifonías de ellas tanto en lo sincrónico como en lo diacrónico (1996: 328). En él se produce un diálogo cultural entre dos autores, sus épocas, sus contextos y los códigos que les permearon y dominaron intelectualmente como bien veía Roland Barthes en $S / Z$. Tanto Cortázar como Benet fueron afectados por él. El segundo, el influido, fue transformado psicológica e ideológicamente por el influyente pero, a un mismo tiempo, aquel, como lector e intérprete de su maestro, lo releyó y le dio nuevos significados. Recordemos que ningún texto en esencia es significativo si no es leído e interpretado. Se trata, por ende, de un proceso de interacción como ve Lara Rallo (2007: 181) o de interdependencia o interconexión como sostiene Allen (2000: 5) en el que el plagio no tiene cabida. Se produce tan solo una estimulante y fértil imitación que abre nuevas plasmaciones literarias. En pocas palabras, Benet, mientras parece despreciar y malinterpretar a su intertexto Cortázar, consciente o subconscientemente lo hereda, incorpora, deforma y transforma para su peculiar proyecto de ficción ambientado mayoritariamente en una fingida Guerra Civil española (1936-9) (víd. Cabrera, Compitello y Herzberger).

Las líneas maestras de esta apropiación intertextual benetiana de toda una tradición de códigos ideológicos y culturales que recibe a través de Cortázar se resumen en las siguientes ideas. Por ejemplo, sus obras son un claro desafío a un manido concepto de realidad. Esta, que es poliédrica y multiforme, depende de los convenios que han llevado a constituir la razón tal y como hoy en día la conocemos. Esta es una que está en un tal vez no imparable proceso de evolución que procede de unas bases artificialmente implantadas que bien pudiera ser que estuvieran equivocadas o que fueran injustas ya que benefician primordialmente a unas élites de poder. La realidad, sus ideas y su tradición son, por lo tanto, subjetivas, criticables, se pueden deconstruir y son renegociables para el argentino (198, 432-3 y 442; las citas se harán de ahora en adelante desde la edición de Rayuela de Edhasa de 1977). Frente a todo absolutismo intelectual, del orden que sea, Cortázar opone un relativismo exacerbado en cuanto a la interpretación del concepto de lo real que es en sí produc- 
Un palimpsesto indeseado en la obra literaria de Juan Benet: Julio Cortázar...

to de un consenso colectivo (Ibid. 507). Sus infinitas caras absurdas (Ibid. 497), sin límites (Ibid. 374), que se esconden más allá de la oscuridad y de lo perceptible (Ibid. 508), así nos lo demuestran y nos hacen desconfiar de sus significados aparentes que reinan en un mundo de seres mentalmente aislados incapaces de sociabilizarse y de comunicarse efectivamente (Ibid. 192-3).

Benet, por su parte, cree que la realidad y que la razón se encuentran en un estado intermedio hacia unos máximos de conocimiento, si es que estos son alcanzables, y que van ampliándose y entendiéndose cada vez mejor a medida que el ser humano y la ciencia van evolucionando. No obstante, en su actual estado tan solo nos ofrecen una visión minúscula y fragmentariamente parcial del todo, aunque esta pueda ser práctica. Además, el autor del celebérrimo ciclo novelístico de Región cree que no es fácil saber dónde están las fronteras entre lo real y lo irreal ya que estas son percibidas deficientemente por nuestros ilusorios e imperfectos sentidos como se puede apreciar en su penetrante libro de ensayos titulado El ángel del señor abandona a Tobías, publicado en 1976 (105-6). Solo desde estas coordenadas intelectuales se pueden entender los perspicaces ataques de ambos autores a lo que hemos considerado que son la razón, la ciencia y su lógica, unas que tan solo operan a escala humana, con sus muchos aciertos y beneficios pero también con sus evidentes limitaciones y errores. La verdadera vida está más allá de ellas para Amorós, siguiendo lo que dice en su introducción a Rayuela (2011: 28).

Además, ambos critican a una ciencia prepotente que tiene un tanto de fe irracional según Machín Lucas («Aproximaciones [...]», 2012: 25) y que se resiste a intuir y a discutir lo que no se puede demostrar empíricamente mediante la experiencia de nuestros sentidos y de nuestra percepción. Es una ciencia que desarrolla e innova más que investiga en aras del pragmatismo, del utilitarismo y de la rentabilidad económica. Sus censuras a ella se aprecian en las explicaciones de temas intelectuales que Cortázar, por ejemplo, hace mediante el añadido pseudofilológico de notas de a pie de página (Rayuela, 415-7) o mediante el uso de tecnicismos (Ibid. 606). De profesión ingeniero civil, Benet se contradice deliberadamente entre su praxis literaria y la científica. Véase sino la animista descripción de la naturaleza regionata, tanto geológica como botánica, al inicio de Volverás a Región, la cual sirve de introducción no solo al cronotopo sino también a la diégesis y a las traumatizadas conciencias de sus personajes a las que incluye y domina. No son el espacio ni el tiempo diseñados por Benet los que imperan. Son esas conciencias que claman las que realmente sirven como auténtico atrezo en esta novela y en otras suyas. Para ello, prefiere un lenguaje de tipo especulativo que desafía la metódica y tradicional lógica cartesiana. El tono de ambos es, así pues, deliberadamente pseudocientífico dada su creencia en la abundancia de puntos ciegos que hay en la razón. 
He aquí más ejemplos al respecto de sus críticas a lo racional. Cortázar denomina a los defensores de la razón como «[...] ciegos de lógica y de buenas costumbres» (Ibid. 200). Para él, lo que entendemos como locura, es decir, como aquello que está fuera de la razón o que quizá la supera, puede ser «[...] un sueño que se fija» (Ibid. 456), idea en deuda con sus influjos surrealistas y del arte del absurdo. Teniendo en cuenta esta idea suya, podemos preguntarnos si la aparente privación del juicio nos puede llevar a acceder a una razón superior o ulterior (Ibid. 93-4). Así resume todo esto con esta sutil paradoja: «[s]ólo viviendo absurdamente se podría romper alguna vez este absurdo infinito» (Ibid. 123). En lo que a Benet se refiere, en Volverás a Región este afirma que la razón está llena de trampas creadas para defender un inestable equilibrio social (137) frente a los más vanos impulsos individuales. Ella es «[...] el auriga de la destrucción» en Un viaje de invierno (128). Puede aniquilar sin escrúpulos a uno o a varios individuos en el altar de los tan cacareados intereses comunes o nacionales como sucedió en esa Guerra Civil española que tanto le traumatizó e inspiró literariamente a Benet. Esto forma parte de las esencias humanas y sobre todo del espíritu regulador de la naturaleza como se ha podido ver en tantas otras deflagraciones bélicas por todo el mundo. En otro orden de cosas, tal y como él lo entiende, tanto lo racional como lo irracional son elementos esenciales de cualquier expresión artística, ya que los dos son inseparables vías de conocimiento y de expresión. Son dos partes inextricables de la misma realidad, la perceptible y la imperceptible que se puede intuir. A saber, una es la comprendida por nosotros aquí y ahora y la otra es la que tal vez en un futuro se descifrará y comprenderá, allí y entonces. Este extracto de la misma novela no puede ser más elocuente, al hablarnos del carácter revelador de lo artístico y de la conciencia humana explicados a un mismo tiempo «[...] por la razón reflexiva y por la conciencia (sinrazón) nostálgica» (Ibid. 310).

Esa revelación de conocimientos varios y ultrasensoriales solo se puede producir en la oscuridad, que no es más que un espacio lleno de luz y de formas que demuestra las limitaciones de nuestra visión individual y colectiva. En esas presuntas penumbras, llenas de claroscuros en las fronteras entre la razón convencional y la sinrazón, pueden aparecer nuevas y superiores respuestas a mucho de lo que desconocemos del mundo, de sus seres y de sus cosas. En Rayuela, obra plagada de «penumbras», se les da a estas hasta diferentes colores, ya que se dice que la sombra puede ser hasta «verde o blanca» (Ibid. 159). En ese espacio invisible yace toda una «ontología empírica» (159) de lo ininteligible (590). Todo el material de una novela se articula inicialmente desde las penumbras, tal y como el mundo fue hecho desde el caos. Ellas son también su tema principal subyacente (458). Para mostrar que todos los seres humanos estamos en la línea divisoria entre la lógica y lo ilógico o entre la cordura 
Un palimpsesto indeseado en la obra literaria de Juan Benet: Julio Cortázar...

y la locura a la que representan irónicamente, aparecen luces que se encienden y se apagan intermitentemente (396).

Benet relaciona esto en buena parte de su producción literaria con la dialéctica existente entre razón y pasión, tema que comparte con Cortázar como se verá en el siguiente párrafo. Entre ambas fuerzas del ser se encuentran sus muy mencionadas «zonas de sombras» con evidentes influencias faulknerianas y de Thomas Mann, entre otros autores. Recordemos que Benet tituló una de sus novelas como En la penumbra (1989). Él advierte las mismas intermitencias que el argentino entre luz y oscuridad cuando, en Un viaje de invierno, dice lo siguiente: «[...] había de ser una velada animada, llena de ruido, de voces y de humo. E instantáneamente todo quedaría en silencio y en penumbra, luz y humo disipándose ante el mismo soplo [...]» (209-210). Las penumbras son, así pues, estados ontológicos, de conocimiento, psicológicos o del alma entre la ignorancia y la lucidez, entre la ceguera total y la plena visión. La también benetiana Saúl ante Samuel, de 1980, está llena de oscuridades. A través de ellas, se puede acceder, desde lo esotérico, a fragmentos de realidades ocultas de sus personajes. Ellas pueden profetizar un futuro condenado a la repetición de los males y a la destrucción argumental y metaliteraria, sobre todo en Una meditación (1970). Como el mismo Benet dijo en una entrevista: «A mí no me gustan las ideas claras, prefiero arreglármelas en la penumbra» (Cartografía, 1997: 298).

Tal y como se anunció previamente, el debate y realimentación mutua entre razón y pasión en la identidad humana y en la social les unifica. Cortázar (457) y Benet hacen prevalecer a la segunda porque puede penetrar intuitivamente en aquellos terrenos a los que la ciencia todavía no ha podido acceder dada la lentitud de su evolución y dado que es el producto de mentes humanas limitadas. Allí se revela el sublime, para Lyotard lo inexpresable y lo inefable (1993: 78-81), una nueva alternativa para entender mejor la desnaturalización de toda una etapa de la humanidad, la postmoderna según la entiende Jameson (1991: 1; víd. también Machín Lucas, «Desafíos postmodernos [...]», 2015: 4-6). Los personajes de Cortázar son emocionales y de una intelectualidad más absurda, surreal y especulativa que lógica. Allá están los Horacio Oliveira, La Maga, Morelli, Gregorovius, Berthe Trépat o Traveler. Es curioso ver que las diferencias que se establecen entre el intelectualoide Morelli y las insatisfacciones sexuales de una vapuleada Maga nos recuerdan en Volverás a Región al reprimido sexual del doctor Sebastián, que trata de aferrarse a sus obsesivas razones para justificarse y para tratar de olvidar sus amarguras, y a Marré Gamallo, que nunca ha podido disfrutar del amor ni de la erótica como deseaba. En muchas otras de las obras benetianas se van alternando, con diferentes características, personajes racionales y pasionales claramente influidos por la filosofía de Nietzsche. Proceden 
de su tratado El nacimiento de la tragedia del año 1872. Benet había leído bastante al filósofo alemán. Esas dos formas del ser parodian la dialéctica nietzscheana entre apolíneos, u hombres espirituales y de reflexión, y dionisiacos, los sensuales o de acción. Machín Lucas (víd. bibliografía) ha estudiado en profundidad esta influencia clave en la obra benetiana.

En consecuencia con todo lo expuesto anteriormente, tanto Cortázar como Benet desconfían profundamente del instrumento más influyente y poderoso de la razón: el lenguaje. Este, al proceder de las mentes humanas, tiene muchas limitaciones para representar lo real, algo que no existe tal y como se nos ha enseñado tradicionalmente, y además distorsiona todo lo percibido. Cortázar cree que el lenguaje convencional no puede en modo alguno reflejar ni describir la realidad en su totalidad (Rayuela, 190, 466 y 500), una que de hecho es fragmentaria como él mismo es (Ibid. 96 e Iwasaki, 2015: 92). Todas sus palabras nunca pueden llegar a comprender ni toda la extensión ni todas las caras de la realidad, sino a tan solo juntar pequeñas partículas de ella y a extraer conclusiones que están todavía lejanas de la verdad absoluta. Y cuando ellas operan dentro del sistema gramatical, del habla y de la escritura, tampoco pueden alcanzar unos máximos de conocimiento aun a pesar de sus infinitas posibles combinaciones y permutaciones. Para Cortázar, la realidad ya está en el lenguaje, en su gramática y en su estilo: «Lenguaje quiere decir residencia en una realidad, vivencia en una realidad» (Ibid. 503).

Por supuesto, se aprecian inmediatamente en estas ideas ecos intertextuales, si bien bastante superficiales, que remiten a la filosofía del lenguaje de un Wittgenstein, expuesta en su Tractatus Logico-Philosophicus (1921) casi medio siglo antes de que se publicaran las producciones de los autores aquí estudiados. De vuelta a Cortázar, su ideario literario nos propone que todo sistema lingüístico edifica y destruye cíclicamente la realidad, similar a lo que un dios Shiva representa para el hinduismo. Todo cambio en el lenguaje equivale inevitablemente a otro en lo real. Solo se puede criticar al sistema desde fuera de él y desde fuera del lenguaje arbitrariamente constituido dado que el que opera en el interior de los dos anteriores está mediatizado por las corrompidas y falsas esencias de «lo real», que no es nada más que un compromiso o un contrato contraído entre los seres humanos para minimizar daños y para maximizar beneficios. Hay otra posibilidad para llevar a cabo esa crítica a la razón práctica: llevar al lenguaje, ya destruido, a un espacio más allá de lo convencional (Ibid. 509), posiblemente para reconstruirlo de nuevo, junto con sus ideas, de manera más sabia y más justa.

Benet hace algo similar en sus ficciones al distorsionar, mediante una hipertrofia de la subjetividad de los narradores o de los personajes, no solo el lenguaje sino también las naturalezas volátiles de la experiencia, de lo rememorado y del cronoto- 
Un palimpsesto indeseado en la obra literaria de Juan Benet: Julio Cortázar...

po, la articulación literaria del espacio y del tiempo. Ello lo consigue, sobre todo en Volverás a Región y Una meditación, con el uso del stream of consciousness. Este es el flujo o corriente de conciencia que en literatura se cristaliza en la técnica del monólogo interior, con sus epifanías, o súbitas manifestaciones espirituales que recuerdan a Joyce, o con sus anamnesis, o reminiscencias, entre adulteradas, inconstantes e involuntarias, que parecen remitir a Proust. Es una memoria que, en la primera de las novelas citadas anteriormente, «[...] desvirtúa, agranda y exagera [...]» lo vivido y que «[...] también inventa» (262). Al no existir ni una realidad ni una razón universales, la memoria las suplanta con su capacidad de recreación y de imaginación y es, en efecto, la que ciertamente se acaba convirtiendo en una fuente inagotable de creencias (Ibid. 20). En cuanto a esto último, Benet confesó haberse inspirado en una frase de Faulkner, procedente de su novela Light in August (Luz de agosto) de 1932, que recordaba decir así: «La memoria cree antes de que el conocimiento recuerde» (Cartografía, 1997: 177). No muy lejos de estas últimas ideas benetianas parece estar Cortázar ya que, para él, estos recuerdos distorsionados por el aparato emocional de una persona son evidencias irrefragables del «[...] idioma de los sentimientos» (Rayuela, 115), uno que, por supuesto, es de naturaleza pasional, engañosa y mudable.

Indudablemente, este tema está íntimamente relacionado con la cuestión temporal, que en ambos autores oscila entre el tiempo cronológico, convencional y pretendidamente objetivo, y el de la conciencia o de la subjetividad. Ambos dan más importancia a este último, el de la durée o duración, formulado por el filósofo francés Henri Bergson. De este modo, pretenden acercarse más fielmente a la naturaleza del individuo para poder representarla de manera más veraz y creíble. Estos dos tipos de tiempo no duran lo mismo para una mente humana si se sienten de manera diferente. Por ejemplo, un hecho apreciado y otro que se percibe como aburrido no son asimilados de la misma manera porque sus medidas dependen de los caprichos del cerebro humano y de sus diferentes coordenadas, con su mudable capacidad de abstracción. Este segundo tiempo lo denomina Cortázar como poético (Ibid. 84), como delicuescente (Ibid. 50), como cíclico y no absoluto (Ibid. 51), como animado y autónomo (Ibid. 80), como uno que se puede abrir (Ibid.93), que se puede anticipar (Ibid. 115), que se puede congelar (Ibid. 335), que es subjetivo (Ibid. 310), que se puede regenerar en uno nuevo (Ibid.), que puede llegar a ser inconmensurable (Ibid. 384) y para el cual toda consumación personal está fuera de su alcance (Ibid. 565). Benet, por su parte, tiene una concepción profundamente pesimista del tiempo. Este está predeterminado por fuerzas impersonales que proceden de la tierra, condenado a una repetición sin visos de la más mínima evolución. Está rodeado de ruinas, de decadencia y de fatalidad que representan las de la conciencia humana. Véanse si 
no estos dos extractos de Una meditación: «[...] el tiempo no se engendró ni en las estrellas ni en los relojes sino en las lágrimas» (71) y «(l)a eternidad concluye; el tiempo vuelve a andar para devorar de nuevo su propio ser, escondido ya en el pecho del hombre $[\ldots] \gg(294)$.

Tanto Cortázar como Benet identifican el tiempo con la lluvia. Así lo expresa el primero: «Qué sé yo lo que es la noche, el tiempo y la lluvia» (Rayuela, 194). Sospechosamente, el segundo escribe algo parecido en Volverás a Región con las siguientes palabras: «Mi padre solía decir: “¿El tiempo?, ¿dónde está eso? Querrás decir la lluvia, la lluvia...”» (163). ¿Es esta una casualidad o una causalidad? ¿Es otra prueba de la relación intertextual entre ambos, por mucho que Benet afirmara despreciar la obra de Cortázar? Los alientos de este y de la tradición que ha recibido pueden haberse infiltrado en el tejido literario benetiano. Con eso no se quiere sostener la idea de que Cortázar sea el pivote en el que Benet se apoya principalmente o el único cedazo que le va tamizando las ideas que se están analizando. Hay muchas otras fuentes, como son la de William Faulkner o la de Thomas Mann, entre otras, que tienen mucha mayor importancia para entender al español. No obstante, es interesante revelar este nuevo palimpsesto, tal vez inconsciente pero no por ello menos valioso. Desde Cortázar, Benet recibe todo el espíritu e innovaciones de una época, traducidas y rediseñadas por su contexto argentino. En definitiva, estos temas acerca de la percepción, de la memoria y del tiempo, tanto como lo metaliterario, lo intertextual y otros de menor calado, generan un espacio superior al de lo hipotéticamente real en sus obras. Es decir, ellos son el auténtico cronotopo de sus novelas dada la ausencia de un referente concreto y específico y dada la imposibilidad de objetivarlo desde los escasos y fragmentarios datos aportados por una conciencia, que filtra y deturpa la experiencia, creada por y para un universo literario de carácter autorreferencial, autorreflexivo y palimpséstico.

Volviendo al tema del lenguaje que dio paso a los de la memoria y del tiempo, algo que es también característico de las artes de ambos escritores hispanos es el uso del oxímoron. Mediante esta figura retórica de pensamiento se combinan dos palabras o expresiones que para la lógica social parecen ser contradictorias. Con ella, se quiere convocar una nueva realidad más abarcadora y profunda que la que hemos heredado y consensuado tradicionalmente, muchas veces sin capacidad crítica. Así se quiere generar nuevos sentidos o más conocimientos siguiendo la dialéctica que se establece entre una tesis y una antítesis, las cuales se realimentan recíprocamente para de esta forma producir una síntesis inesperada. Como ejemplo de ello, Cortázar sugiere que de la combinación entre el interés y la falta de él debe nacer algo nuevo (Rayuela, 335). También dice que existe «[...] la verdadera luz negra» (Ibid. 52), oxímoron típico de la mística que remite a un Dios del que por cierto apenas habla 
Un palimpsesto indeseado en la obra literaria de Juan Benet: Julio Cortázar...

este autor marxista. Incluso afirma que «[...] los dos se admitían y se rechazaban en el mismo momento» (Ibid. 60), que «[...] él sabía sin saber» (Ibid. 388), que se sentía «[...] que el asesino no era un asesino», que algo era «[...] lo único sensatamente insensato» (Ibid. 389), y que hay «[...] dos maneras, necesitadas de que la una quede abolida en la otra y viceversa» (Ibid. 394). Más ejemplos de oxímoron se pueden encontrar en esta caleidoscópica obra. Por ejemplo: «[...] nada está perdido si se tiene por fin el valor de proclamar que todo está perdido» (Ibid. 433) o «[...] (e)se mundo no existe, hay que crearlo como el fénix. Ese mundo existe en éste [...]» (Ibid. 435). En En el estado, novela de Benet, publicada en 1977, esta es la manera en la que uno de sus personajes, el señor Hervás, es descrito: es «[...] contradictoriamente gordo y delgado, ancho y estrecho, consumido y lozano, vestido con unas ropas que tanto le vienen holgadas como cortas» (14). Estamos ante la enigmática «retórica del oxímoron» para el crítico benetiano Benson (2004: 29). Ella surge de la interesante interacción que se produce en esta «coincidentia oppositorum» que finalmente no se anula ni contradice a sí misma, sino que genera una nueva secuencia de contradicciones hasta el infinito creadas por sus lectores.

Otro mecanismo novelístico construido por ambos escritores que pretende demostrar que no podemos percibir la realidad de una única manera fija es el que distingue la imagen estática de la secuencia de ellas, algo que nos recuerda a la dicotomía entre fotografía y cine. Las vinculaciones entre literatura, imagen y séptimo arte, aunque nacieran en el siglo XIX, son básicamente fundamentales para entender el imaginario literario sobre todo desde el XX en adelante, ahora multiplicadas por el influjo de la aldea virtual. Ambas técnicas visuales se han convertido en palimpsestos indiscutibles de la escritura. En ella, metaforizan dos modos posibles de acceder a y de representar fracciones de «lo real» y del conocimiento con diferentes formas, estéticas y velocidades narrativas. Entre las muchas de ellas se destacarían las siguientes. Con el uso exclusivo de la imagen estática, el tiempo se congela. Esto puede remitir al carácter obsesivo de la conciencia que idealiza o que está traumatizada o al hecho de estar esta visualizando la experiencia ajena, de la que se poseen pocos, seleccionados y distorsionados datos ya que el que la cede generalmente omite ex profeso información perjudicial para él. Esto se lleva a cabo muchas veces mediante el uso del leitmotiv, es decir, de la repetición de un motivo central al que rodean otros de menor importancia que sirven para explicarlo y (re)definirlo. También puede emparentar las obras con la técnica cubista de tipo pluriperspectivista, como cuando se combina una imagen con otras que aluden a hechos, a tiempos y/o a espacios diferentes vividos por un mismo personaje o por varios, mostrados a un mismo tiempo, o como cuando se examina la realidad en sincronía desde diversos puntos de vista 
estáticos procedentes o bien de un mismo personaje o bien de varios a la vez con la intención de hallar nuevas explicaciones a lo acaecido.

Estos son unos breves ejemplos teóricos que resumen las infinitas formas de destacar, de combinar y de permutar hechos clave para entender la diégesis narrativa. Por otra parte, la secuencia de imágenes que corresponde a un mismo hecho busca atrapar el tiempo en su esencia más natural, aunque es inviable y ni tan siquiera el realismo la usó de manera completa y coherente. Para Benet, ese movimiento tan simplista se basó más en el uso de la estampa y en su sucesión en lo argumental sobre todo a principios del XIX (La inspiración y el estilo, 150). No obstante, representar el fluido del tiempo es imposible dadas las limitaciones de lo textual y de lo cognitivo. De hecho, la secuencia está distorsionada por su posición diegética con respecto a otros hechos, por la cantidad de datos o imágenes que suministre y por la relevancia narrativa que estos tengan para sus lectores, entre tantos otros factores que alteran una aparente sensación de realidad y toda su percepción. Esto hace que dicha secuencia adquiera diferentes velocidades, algo que está íntimamente relacionado con la subjetividad y con los horizontes de expectativas de los lectores explícito (el destinatario del discurso) e implícito (el receptor inmanente que interpreta la obra más allá del tejido discursivo).

Ni que decir tiene que esas estrategias y velocidades dependen también de si estas imágenes o sus secuencias aluden a la más vívida experiencia personal o a la más impersonal de las vivencias del otro, con sus implicaciones emocionales. He aquí lo que Cortázar resume acerca de este infinito espectro de posibilidades de combinar y de distribuir la imagen y su secuencia entre los lectores: «[...] la vida de los otros [...] no es cine sino fotografía [...] fragmentos eleáticamente recortados [...] instantes fijos» (Rayuela, 532). También dice que se debería de «[...] dar coherencia a la serie de fotos para que pasaran a ser cine» (Ibid.). En La inspiración y el estilo, Benet genera y articula la dicotomía entre argumento y estampa y en su artículo «Onda y corpúsculo en el Quijote» establece una similar entre esos dos conceptos, que como se puede entender fácilmente se corresponden respectivamente con los de secuencia de imágenes e imagen en sí. Son para él «dos apetitos de descripción y justificación [...]» (150) de la obra. O sea, ambos aluden a su carácter eminentemente autorreferencial, desvinculado de toda representación fiel de «lo real», un concepto inverosímil para ellos, toda una entelequia, toda una quimera.

Obviamente, a sabiendas del desprecio manifiesto de ambos autores al valor de lo argumental, estos le van a dar más importancia a la estampa en su praxis novelística. El argumento no es de fiar dada la mala memoria del escritor a la hora de montar la arquitectura de la trama y dados su carácter selectivo y su carencia de muchos materiales y herramientas de tipo lingüístico, cognitivo y lógico. La primera razón 
Un palimpsesto indeseado en la obra literaria de Juan Benet: Julio Cortázar...

puede provocar innúmeras incoherencias. De allí se deriva la querencia de ambos por las dobles lecturas que llevan a infinitas de ellas. Esto sucede con Rayuela y con el surgimiento de infinitud de interpretaciones que se producen tras su lectura dual en la mente de sus lectores implícitos, aquellos que reconstruyen sus lagunas y sus puntos vacíos en su discurso narrativo. En Benet, esto se aprecia en Un viaje de invierno desde la interacción entre el texto principal y las notas marginales que simulan explicar al anterior aunque acaben abriendo espacio a más dudas e interrogantes. Nunca se desvelan verdades irrefutables en sus obras. En este orden de cosas, otro ejemplo que conviene destacar de Benet es el de las deliberadas contradicciones que existen entre el mapa geográfico, inserto en el libro (la denominada como «cartografía benetiana»), y el texto en Herrumbrosas lanzas (1983-86). En consonancia con todo esto, está el hecho de que para Cortázar el centro está en los márgenes (Rayuela, 625), lo que quiere decir que los márgenes se han convertido en el nuevo centro de reflexiones tras haber sido olvidados durante mucho tiempo de falogocentrismo (o de construcción de discursos de origen masculino para Derrida) y de imperio del poder oficial y económico. Ello quiere decir que los centros ontológicos, ideológicos, gnoseológicos y metafísicos se han desplazado de su posición tradicional, consensuada política, social, económica, cultural e históricamente. Ello es visible en la forma o en la estructura de las novelas de ambos, en sus múltiples temáticas o en sus personajes descentrados, siempre en cuanto a su identidad y en cuanto a su relación con la alteridad.

Hay asimismo un tema que parece vincular a ambos con ciertas tradiciones religiosas, místicas o de filosofías de vida de carácter sincrético como pueden ser la católica, la cabalística, el sufismo o el taoísmo, posiblemente tomadas de segunda mano y formuladas sin gran profundidad. Es el deseo de todo ser humano de encontrar respuestas al misterio de la vida, aunque ese haya sido desechado hace tiempo en busca de resolver activamente su conflicto con unas imprecisas e indefinidas experiencia perceptiva y razón práctica. Se evidencia de este modo en sus obras una obsesiva nostalgia, similar a la que sienten todos los seres humanos, por la esencia originaria que nos dio la vida como seres individuales. Es un poético deseo de ir hacia las raíces de la creación para tratar de entender mejor sus vidas, sus seres, sus contextos y sus destinos y para tratar de encontrar lo esencial de un mundo intoxicado para ayudar a depurarlo. Es el eterno, cíclico retorno de toda la humanidad al paraíso perdido de la infancia, al útero materno y a la sopa primigenia, un momento incorrupto añorado que se quiere oponer a la hipocresía, a la vileza y a la ignominia características de la historia común, la de los intereses creados. Ciertos críticos literarios han advertido la importancia de este tema poco estudiado en estos dos autores. Por ejemplo, el de sus imaginaciones ha de ser un itinerario tanto espacio-temporal 
como intelectual que se ha de encaminar hacia una trascendencia de orden metafísico de acuerdo con Aguilar Monsalve («Rayuela [...]», 163). Y no solo eso, sino que también es toda una «[...] ansiedad metafísica [...]» que se propone llegar al centro de la ipseidad para que uno se conozca mejor según Carrión, la cual lo percibe en esa misma novela (2015: 22).

A pesar de ser este un tema muy superficialmente trabajado por Cortázar y usado por él de manera un tanto lúdica y burlesca, no es en absoluto baladí a tenor de lo que insiste en él en la obra objeto de estudio (véase, por ejemplo, en Rayuela entre las páginas 51 y 53 , en la 65 , entre la 432 y la 433 , entre la 485 y la 486 y entre la 558 y la 560). Esta temática demuestra preocupaciones existenciales en su subconsciente, planteadas de manera alternativa. Con todo, las desprovee de sus orígenes y, como ya se ha dicho, de su profundidad mística. Las parodia, así pues, no sin mucha ironía, influida esta por su descreimiento o escepticismo en lo esotérico y por sus innegables vinculaciones con el relativismo religioso de gran parte de la izquierda. Pero eso no es óbice para reconocer que, de todos modos, este escritor acaba insinuando la existencia de un espacio-tiempo de silencio presemiótico, pregramatical y presemántico, en donde se encuentra el origen de todas las cosas, incluida la palabra esencial o matriz de la que dimanarán todos los lenguajes y sus sistemas lingüísticos correspondientes para la formación de la cultura tal y como la conocemos (Ibid. 483).

Este tema es formulado con más profundidad por Benet y tiene una mayor incidencia en el sentido de sus exiguas tramas (víd. Machín Lucas, «Los palimpsestos [...]», 2015). Para él, toda vuelta al origen es un proceso de retracción o de retroceso, una manera de exorcizar una historia marcada por la injusticia social y por los abusos. Como no hay solución a estos problemas en una Tierra predeterminada por la tradición y por un control del poder por parte de unas minorías, algunos de sus personajes anhelan encontrarla más allá de la muerte. Allí, el mundo redentor divino es metaforizado por esos espacios en penumbras y tan llenos de contenidos y por el del silencio que alberga sonoridades a las que ciertos humanos y animales pueden acceder, o intuitivamente mediante sextos sentidos o mediante percepciones más desarrolladas. Es muy sintomático lo que Benet expresa en su libro de ensayos titulado El ángel del señor abandona a Tobías, de 1976. Este deseo es para él un tipo de nostalgia por el tiempo absoluto del origen (134-5). En Volverás a Región se comenta la posibilidad del posible renacimiento de una humanidad más perfecta tras aprender de nuestros errores y tras volver al útero materno (154). Por supuesto, esta es tan solo una idea literaria, compartida no solo por místicos sino también por muchos otros literatos, entre los que cabría destacar a poetas como Juan Ramón Jiménez, Octavio Paz, José Ángel Valente o Antonio Gamoneda, a narradores como Alejo Carpentier o a filósofos como María Zambrano o Eugenio Trías. También nos 
Un palimpsesto indeseado en la obra literaria de Juan Benet: Julio Cortázar...

recuerda a las películas Miracolo a Milano, de 1951, de Vittorio De Sica, o a las de Andréi Tarkovski como Solaris de 1972, Stalker de 1979, Nostalgia de 1983 o Sacrificio de 1986, entre muchos otros ejemplos contemporáneos. En ellas, toda solución a nuestros males reside en el más allá.

En suma, estas han sido las más importantes y dolosas de las minúsculas pedanterías que Benet atribuía y reprochaba a Cortázar pero que compartía con él desde una tradición común, desde pensamientos paralelos producto de su pertenencia a una misma época o a una misma identidad -la hispana- o, en algunos casos, desde una posible usurpación intertextual. En este último aspecto, cabe decir que transforma el pensamiento del argentino con su feraz imaginación. Los palimpsestos más indeseados también pueden ser los más motivantes tanto por imitación como por reacción a ellos. Los varios exabruptos insustanciales dedicados por el madrileño a esta figura literaria y los pocos datos suministrados, entre ellos la fecha exacta de sus lecturas, no impiden rastrear y detectar una serie de similitudes que se han evaluado y analizado como posibles influencias. Sus comentarios contra todo tipo de sistemas culturales absolutistas y de pensamiento único y contra unas estereotipadas nociones de realidad y de razón pretenden desplazar la tradición oficial hacia los márgenes de la razón práctica o incluso hacia sus límites, hacia los espacios que residen más allá de la percepción o en el origen humano. Estos últimos han sido olvidados por la historia tan solo por su escasa rentabilidad sin tener en cuenta su interés como vías alternativas de conocimiento hacia una verdad subjetiva, atomizada, relativa y polimorfa. Para ello, dialogan con un lector activo reduciendo el desarrollo de lo argumental y aumentando el del estilo, el de la digresión y el de una especulación pseudointelectual, bastante pretenciosa en su carácter lúdico y erudito pero desprovista de ínfulas científicas. Su propósito es el de reeducarlo, el de acostumbrarle a una disciplina intelectual superior a la lógica de a diario. Lo interesante es haber abierto esta nueva vía de discusión para conocer mejor a dos de las mayores figuras de la literatura hispana del siglo XX, con gran proyección y prestigio internacional, y para entender mejor las más que posibles influencias de Cortázar en Benet. Para entender bien a un escritor, no es conveniente limitar los conceptos de intertextualidad o de palimpsestuosidad a aquellas lecturas admiradas. Las supuestamente detestadas también alimentan a un espíritu inquieto intelectualmente y le influyen tanto por acción como por reacción, consciente e inconscientemente, como sucede entre generaciones o entre padres e hijos. 


\section{Bibliografía}

Aguilar Monsalve, Luis A., «Lo fantástico, lo ilógico y lo irreal en la narrativa hispanoamericana del siglo XX», en ed. Jorge Machín Lucas, Aproximaciones (supra), (intra) y (extra)literarias a lo irracional en las letras hispanas de los siglos XX y XXI: un esbozo de teoría del caos. La nueva literatura hispánica, 16, 2012, págs. $55-79$.

---, (ed.), Y el hombre dio su vuelta en ochenta mundos...(Homenaje a Julio Cortázar) (1914-2014), Quito, LAAM Editores, 2015.

---, «Rayuela: reivindicadora de una nueva latinoamericanidad», en ed. Luis A. Aguilar Monsalve, $Y$ el hombre dio su vuelta en ochenta mundos... (Homenaje a Julio Cortázar) (1914-2014), Quito, LAAM Editores, 2015, págs. 159-175.

Allen, Graham, Intertextuality, London and New York, Routledge, 2000.

Bakhtin, M(ikhail) M(ikhailovich), The Dialogic Imagination: Four Essays, ed. Michael Holquist, trans. Caryl Emerson and Michael Holquist, Texas, University of Texas Press, 1996.

Barthes, Roland, S/Z, trans. Richard Howard, New York, Hill and Wang, 1974.

Benet, Juan, La inspiración y el estilo, Barcelona, Seix Barral, 1973. (Con dos textos de C. Martín Gaite, Madrid, Alfaguara, 1999).

---, Volverás a Región, Barcelona, Destino, 1967.

---, Una meditación, Barcelona, Seix Barral, 1970.

---, Un viaje de invierno, ed. Diego Martínez Torrón, Madrid, Cátedra, 1989.

---, El ángel del señor abandona a Tobías, Barcelona, La Gaya Ciencia, 1976.

---, En el estado, pról. Juan Benet, coloquio entre Juan Benet, José María Martínez Cachero y Darío Villanueva, pról. Vicente Molina Foix y epíl. Javier Marías, Madrid, Santillana (Alfaguara), 1999.

---, Saúl ante Samuel, ed. John B. Margenot III, Madrid, Cátedra, 1994.

---, Herrumbrosas lanzas, Madrid, Santillana (Alfaguara), 1998.

---, En la penumbra, Madrid, Santillana (Alfaguara), 1989.

---, Cartografía personal, Valladolid, Cuatro. Ediciones, 1997.

---, «Onda y corpúsculo en el Quijote», en Juan Benet, Infidelidad del regreso, Valladolid, Cuatro. Ediciones, 2007 págs. 29-60.

Benson, Ken, Fenomenología del enigma. Juan Benet y el pensamiento literario postestructuralista, Amsterdam-New York, NY, Rodopi, 2004.

Bergson, Henri, Durée et simultaneité, Paris, Presses Universitaires de France, 1998.

---, Materia y Memoria. Ensayo sobre la relación del cuerpo con el espíritu, Buenos Aires, Editorial Cactus, 2006. 
Un palimpsesto indeseado en la obra literaria de Juan Benet: Julio Cortázar...

Bloom, Harold, The Anxiety of Influence, New York, Oxford University Press, 1973.

---, A Map of Misreading, New York, Oxford University Press, 1975.

Cabrera, Vicente, Juan Benet, Boston, G. K. Hall, Twayne World Author Series, Twayne Publishers, 1983.

Carrión de Fierro, Fanny, «El incansable juego de la vida en la narrativa de Julio Cortázar», en ed. Luis A. Aguilar Monsalve, $Y$ el hombre dio su vuelta en ochenta mundos... (Homenaje a Julio Cortázar) (1914-2014), Quito, LAAM Editores, 2015, págs. 17-33.

Compitello, Malcolm A., Ordering the Evidence: «Volverás a Región» and the Civil War Fiction, Barcelona, Biblioteca Universitaria Puvill, 1983.

Cortázar, Julio, Rayuela, Barcelona, Edhasa, 1977.

---, Rayuela, ed. Andrés Amorós, Madrid, Cátedra, 2011.

---, Las armas secretas, ed. Susana Jakfalvi, Madrid, Cátedra, 2004.

---, La vuelta al día en ochenta mundos, vol. 1, México, Siglo XXI, 2005.

---, La vuelta al día en ochenta mundos, vol. 2, México, Siglo XXI, 2005.

---, Bestiario, Madrid, Punto de lectura (Santillana), 2016. 2016.

---, Historias de cronopios y de famas, Madrid, Punto de lectura (Santillana),

---, Todos los fuegos el fuego, Madrid, Punto de lectura (Santillana), 2016.

Faulkner, William, Luz de agosto, Madrid, Santillana (Alfaguara), 2010.

Genette, Gérard, Palimpsests: Literature in the Second Degree, trans. Channa Newman and Claude Doubinsky, fore. Gerald Prince, Lincoln, Ne \& London, University of Nebraska Press, 1997.

Hassan, Ihab, The Postmodern Turn: Essays in Postmodern Theory and Culture, Columbus, Ohio State University Press, 1987.

Herzberger, David K., The Novelistic World of Juan Benet, Clear Creek, Indiana, The American Hispanist, 1976.

Iwasaki, Fernando, «Instrucciones para leer a Cortázar», en ed. Luis A. Aguilar Monsalve, $Y$ el hombre dio su vuelta en ochenta mundos... (Homenaje a Julio Cortázar) (1914-2014), Quito, LAAM Editores, 2015, págs. 91-103.

Jameson, Fredric, Postmodernism, or, The Cultural Logic of Late Capitalism, Durham, Duke University Press, 1991.

Kristeva, Julia, El texto de la novela, Jordi Llovet (trad.), Barcelona, Lumen, 1981.

Lara Rallo, Carmen, Las voces y los ecos. Perspectivas sobre la intertextualidad, Málaga, Analecta Malacitana, 2007. 
Lotman, Yuri, Analysis of the Poetic Text, ed. and trans. Barton D. Johnson, Ann Arbor, Ardis Publishers, 1976.

Lyotard, Jean-François, The Postmodern Condition, trans. from French by Geoff Bennington and Brian Massumi, Minneapolis, University of Minnesota Press, 1993.

Machín Lucas, Jorge, «Juan Benet al trasluz: palimpsestos subversivos en Región», Cuadernos hispanoamericanos, 609, marzo de 2001, 19-28. («Region jako palimpsest», trad. al polaco por Barbara Jaroszuk, Literatura na świecie, 1-2, 426427, 2007, págs. 56-65.

---, El primer Juan Benet (1965-1972): La forja de un estilo novelístico, Saarbrücken, VDM Verlag, 2009.

---, «Aproximaciones (supra), (intra) y (extra)literarias a lo irracional en las letras hispanas de los siglos XX y XXI: un esbozo de teoría del caos», La nueva literatura hispánica, 16, 2012, págs. 9-54.

---, «Las raíces nietzscheanas de Juan Benet (1927-1993)», Revista Cronopio, 49, 2014. http://www.revistacronopio.com/?p=12510

---, «Desafíos postmodernos de la obra literaria de Juan Benet», Comunicación, 24, 2, año 36, 2015, págs. 1-24.

---, «Los palimpsestos de Jenofonte, de la mística y de Nietzsche en la narrativa de Juan Benet», Ínsula, 825, año LXX, septiembre de 2015, págs. 8-11.

---, «Filosofía, intertextualidad y postmodernismo: la influencia de Friedrich Nietzsche en la obra novelística y en la ensayística de Juan Benet», Tropelías: Revista de Teoría de la Literatura y Literatura Comparada, 23, 2015, págs. 332-356. file://C:/Users/machin-lucas-j/Downloads/663-2241-1-PB\%20(7).pdf

---, «El palimpsesto de La montaña mágica de Thomas Mann en la obra literaria de Juan Benet», 1616: Anuario de la Sociedad Española de Literatura General y Comparada, 6, 2016, págs. 171-194. file:///C:/Users/machin-lucas-j/Downloads/1596855512-1-SM.pdf

---, «Diálogos (sub)conscientes transatlánticos: de Rayuela de Julio Cortázar a la obra literaria de Juan Benet», Tonos Digital. Revista de estudios filológicos, 34, enero de 2018, págs. 1-16. file:///C:/Users/machin-lucas-j/Downloads/1881-5375-1PB\%20(5).pdf

Machín Lucas, Jorge \& Jason Tentinger, An Original Translation of Trece Fábulas Y Media Y Fábula Decimocuarta, Barcelona, PPU, 2010.

Mann, Thomas, La montaña mágica, trad. Isabel García Adánez, Barcelona, Edhasa, 2009.

Minardi, Adriana, Historia, memoria, discurso. Variaciones sobre algunos ensayos benetianos, Madrid, Pliegos, 2012. 
Un palimpsesto indeseado en la obra literaria de Juan Benet: Julio Cortázar...

Nietzsche, Friedrich, El nacimiento de la tragedia o helenismo y pesimismo, trad. y notas de Germán Cano, en Nietzsche, Vol. I, intr. Germán Cano, Madrid, Gredos, 2009, págs. 32-185.

Wittgenstein, Ludwig, Tractatus logico-philosophicus, trad., introd. y notas de Luis M. Valdés Villanueva, Madrid, Tecnos, 2008. 